\title{
Revitalization of Customary Court in the Juvenile Criminal Justice System in Indonesia
}

\author{
Nur Rochaeti ${ }^{1,}$, and Rahmi Dwi Sutanti ${ }^{1}$ \\ ${ }^{1}$ Faculty of Law, Diponegoro University, Semarang, Indonesia
}

\begin{abstract}
At present in Indonesia, the existence of customary court in society is still recognized as a mechanism that is applied in solving the problems of customary or criminal violations, which are carried out without involving the law enforcement officers. This study aims to answer two problems. The first is how the customary court in the Dayak Kanayatn tribe and the second is how revitalization customary court in the juvenile justice system in Indonesia. The research will be conducted in Pontianak, West Kalimantan. The method used is a socio-legal research, which analyzes the legal implementation based on legal and society. The results showed that Dayak Kanayatn indigenous peoples have customary court mechanisms capable of solving community problems based on collective agreements and various existing sanctions show that customary court in the community is able to provide a sense of justice in handling cases that occur in the community and the revitalization of customary court in the juvenile criminal justice system in Indonesia needs to be done through a mechanism of participation of traditional people as an alternative in solving problems with customary law characteristics, cultural pluralism, moral values, and religion that bring the best interest for children.
\end{abstract}

\section{Introduction and literature review}

The function of the law is as a means of community renewal and community protection, thus it is necessary to organize a comprehensive and integrated legal system by recognizing and respecting the religious and customary law and renewing the law in accordance with the demands of reform through legislation program.

The existence of customary law communities is recognized and regulated in Article 18B of the 1945 Constitution of the Republic of Indonesia, which are:

(1) The State recognizes and respects units of regional government that are special or exceptional which are regulated by the law.

\footnotetext{
*Corresponding author: etikfh@undip.ac.id
} 
(2) The State recognizes and respects units of the community of customary law community and their traditional rights as long as they are alive and in accordance with the development of society and the principles of the Unitary State of the Republic of Indonesia, which are regulated by the law.

It is also regulated in Article 103 letter a of Act No. 6 of 2014 on Villages, that the regulation and implementation of governance by traditional villages are based on the original arrangement. The original arrangement is a system of traditional village life organizations known in their respective regions. In the formulation of Article 103 letter a, associated with Article 103 letter d and e of the Village Act, the traditional village court institution is the customary court which is known by the community of customary law, both those which have the function to decide, and those that function is to reconcile customary disputes based on customary law. This means the Court that is known by the community of customary law is then recognized as customary village courts in the formulation of The Act No. 6 of 2014 on Villages.

The role of society in restorative justice in the juvenile criminal justice system is very important, because basically, it is a manifestation of a "legal cultural values" system, from the understanding of the implementation. The restorative justice even will fail if the community does not participate in the implementation. Restorative justice in Indonesia has a different basis from its development in the Western world because this is a thought in the effort to reduce child delinquency, based on local wisdom, values, morals which have been a guideline for the community in a behavior that prioritizes more about reaching an agreement.

The Act No.11 of 2012 on the Juvenile Criminal Justice System, it explains how the judicial process against children in conflict with the law is. In The Act No. 35 of 2014, the amendment of The Act No.23 of 2002 on Children Protection, it also explains how a child has the right to protection and "special" treatment if the child is in an emergency situation such as being a suspect in a crime, violence, exploitation, and others.

\subsection{Revitalization of Customary Justice}

In Indonesia, the characteristics of customary law in each region have a solution mechanism in dealing with customary conflicts and customary offenses. The existence of customary justice in several regions is still recognized and implemented in an effort to gain access to justice. Marc Levin states that the approach which was formerly stated to be outdated, old-fashioned and traditional is now expressed as a progressive approach [1].

According to Van Ness, the customary justice process significantly is a form of restorative justice, at least in three forms. First, the existence of two characteristics of the restorative justice program which is an adaptation of customary practices: the conference system (found in Maori traditional practices in New Zealand) and a circular system (the first practice was in America). Second, the philosophical basis for the customary process is that the judiciary seeks to improve the crime structure in the society that injures and provides information about restorative justice. Third, some forms of customary justice have been included in formal efforts in the crimes handling the process [2].

According to Hildreed Greertz, the basic values of community culture are a) "Urmat" (respect) and b) "Rukun" (maintain social harmony). Urmat is a rule that says that in every situation, human should behave in such a way that their way of speaking and behaving always show respect for others according to their level and position. "Rukun" is an attitude that has a social dimension, which aims to maintain the society to be always in harmony. The social behavior of Javanese individuals always prioritizes those two basic rules, which 
are behaving respectfully according to their level and position and actively participating in maintaining harmony in their social context [3].

According to Hart, customary law is closer to the order of "primary rules of obligation" than the state law which is made intentionally (purposeful) and therefore closer to the order of "secondary rules of obligation". Customary law is closely related to local culture. The word "culture" shows a strong emotional-traditional element in customary law. Customary law is also a law that is full of certain value-laden [4].

The existence of customary law, according to Satjipto Rahardjo based on the perspective of legal sociology, is suggested to pay attention to, care for and consider of: 1) That for the state government to adjust their position towards customary law; 2) Recognizing that local communities and customary law are part of the body of the state, and the flesh and blood of the country itself. Therefore, the state is expected not to be the antagonist, but the protagonist when confronting the local community with all its laws; 3 ) The state government indeed has the privilege of regulating and interfering in society. In the Indonesian socio-anthropological context, this right should be subject to the spirit of feeling empathy, concern, and care for how local people accept their traditional and local law. Governing this diverse country and nation, it cannot only use the brain but more with the conscience; 4) It is recommended that our knowledge of customary law be enriched with the local law, as a distinct type. It is a type of law that is closely linked to the customs, local values, and religion [5].

Various cultures, the diversity of behavioral habits in Indonesian society is a valuable treasure which becomes a guideline for the society to play a role, to participate in the restorative justice process. This was also conveyed by John Braitwhite, as follow:

"The types of restorative justice standards are articulated: limiting, maximizing, and enabling standards. They are developed as multidimensional criteria for evaluating restorative justice programs. A defense of the list is also articulated in terms of values that can be found in consensus UN Human Rights agreements and from what we know empirically about what citizens seek from restorative justice. ultimately, such top-down lists motivated by UN instruments or the ruminations of intellectuals are only important for supplying a provisional, revisable agenda for bottom-up deliberation on restorative justice standards appropriate to distinctively local anxieties about in justice" [6].

In general, the norms and habits related to everyday life in indigenous peoples are the law that applies in the community itself because it is a product of acceptance and approval of public opinion as a whole.

\subsection{Juvenile Criminal Justice System}

The Juvenile Criminal Justice System is a system in handling juvenile offender, which consists of institutions that handle Children Investigations, Children Prosecutions, Children's Courts, Children Correctional Services. The Juvenile Criminal Justice System is implemented by still considering the children's welfare, because a) Children are the potentials and successors of the nation in which the foundation has been built by the previous generation; b) In order for each child is able to take the responsibility, he/she needs to have the opportunity to grow, and develop naturally; c) In the society, there are children who experience obstacles in their well-being physically, mentally, socially and economically; d) Children cannot maintain themselves yet; e) These barriers can be eliminated only if the children's welfare guaranteed [7].

The reformist group thinks that the resolution using penalty in the juvenile court cannot overcome crime. The abolitionist group considers that the criminal justice only imposes its 
decision, based on the interpretation of norms and values produced by the consensus, which is considered the most correct (consensus model). The criminal justice based on this model has never created an understanding, for the perpetrators of the crime and for the victim. Criminal law is only harsh against people, but not against the crimes [8].

Based on the Convention on the Rights of the Children, Article 40, there are principles of protecting the rights of the children who violate the law which generally emphasizes the principle of children's welfare and proportionality. The prosperity can be realized by conducting a judicial process without any violence physically and psychologically, whether during the examination process or after undergoing a court decision.

Revitalization in the scope of the criminal law system reform includes the following: a) Legal substance (substantial system), includes the renewal of material criminal law, formal criminal law, as well as criminal implementation law; b) Legal culture (cultural system), includes renewal of the perpetrator's moral, as well as legal education in criminal law; c) Legal structure (structural system), includes the renewal of the investigatory body, prosecutors body, court body, and criminal execution and court body [8].

The Customary court and Restorative justice are efforts to re-discover the values of local wisdom, cultural diversity, and custom as a basis in handling the upcoming children's delinquency using restorative justice at the juridical level, as well as the application of more concrete steps, to implement noble cultural values in the customary law as a characteristic of Indonesia which is an effort to protect while at the same time prospering the society.

\section{Objective of the study}

The customary society can participate in the juvenile criminal justice system. The handling in the Customary court is considered as an option to provide a justice mechanism other than those used in the criminal justice system. The object of the study is the revitalization of the customary court in the Juvenile Criminal Justice System in Indonesia.

\section{Methodology}

The method of this research uses the Socio-Legal Research approach. Based on this approach, it will be found legal pluralism in Indonesia. In addition, using the Socio-Legal Research approach, it will be found problems related to the revitalization of customary justice in the juvenile criminal justice system in Indonesia.

A socio-legal study is an alternative approach that examines doctrinal studies of law. The word "socio" in socio-legal studies represents the relationship between the contexts in which the law exists (an interface with a context within which law exists). Therefore, when a socio-legal researcher uses social theory for analytical purposes, they are often not aiming to pay attention to sociology or social science alone, but also focus on law and legal studies [9]. 


\section{Discussion}

\subsection{Customary Court in the Dayak Kanayatn Tribe Society in Korek Village, Sungai Ambawang Sub-District, West Kalimantan}

Dayak Kanayatn is one among hundreds of Dayak sub-tribes that inhabit the Kalimantan island, precisely in the Landak District, Mempawah District, Kubu Raya District, and Bengkayang District. The customary law of Dayak Kanayatn has a territorial unit called binua. Binua is an area consisting of several villages (formerly Radakng/Bantang). Each binua has its own autonomy, thus one binua community cannot intervene in the customary law of another binua. Each binua is led by a timanggong (head of head). Timanggong has subordinates. They are Pasirah (traditional leaders) and Pangaraga (customary lawyers). These three pillars are the traditional institutions of Dayak Kanayatn.

The verbal traditions of Dayak Kanayatn are the same with all customs apply to their lives. This custom covers all aspects of life and influences people's lives. It regulates the lives of people in interacting. When the Dayak Kanayatn community violates the customary law, they will feel more ashamed than when they violate the government regulations. This is because the custom is a rule inherited from the ancestors which are universal and binding. By disrespecting the custom means "uncivilized". When a Dayak Kanayatn is not civilized, then they are not considered as Dayaks. These things are the reason why verbal traditions and customs are highly respected and upheld in the lives of their people. The verbal tradition of Dayak Kanayatn is very much related to the ceremony. All social, behavioral and ceremonial arrangements in the Dayak Kanayatn community are regulated by the custom and there will be sanctions for each violation.

The procedure for traditional punishment is by giving sanctions for violation which is committed by a person/group of people in the local society themselves. There are, for example, adat bata api, adat balaki-babini sakamarkapala. The penalties or sanctions are in the form of goods (plates, chopper, gongs) and animals, particularly chicken and pig. However, it is now slowly changing into money. This happens since it is difficult to find the items nowadays.

\subsection{Revitalization of Customary Court in Juvenile Criminal Justice Systems in Indonesia}

Revitalization of customary justice is an effort to realize the national legal system which includes the development of legal substance, both written and unwritten law, the improvement of legal structure for efficiency and the best benefits of children in the Indonesian juvenile criminal justice system, and the involvement of all society components to support the law development which is fair and based on the moral values of Pancasila.

The existence of customary law in the criminal justice system is regulated in Law Number 48 of 2009 regarding Judicial power, Article 5 paragraph (1) which states: "Judges and Constitutional Justices are obliged to explore, follow, and understand the legal values and sense of justice that exists in the society".

This is an opportunity to give power to judges to explore, follow and understand the customary law and make it a basis of consideration in deciding the handled cases. However, there is still a need for a customary justice mechanism that is given independent authority to handle cases, particularly children cases, which relates to the best benefits for the children with non-penal processes and non-stigma decisions. Even though the current criminal justice system requires restorative justice, it is important to revitalize customary justice as a sub-system in the juvenile criminal justice system. 


\section{Conclusion}

Based on the results of the research, it can be concluded that the traditional people in West Kalimantan and Indonesia recognize the existence of customary justice as an attempt to deal with cases that occur in their environment, as well as children-related cases. Substantially, the customary law and its legal sanctions still apply to traditional people. Structurally, the customary justice mechanism is still implemented and its existence is recognized. In a legal culture, the people still respect and follow the decisions given through the customary courts. Dayak Kanayatn indigenous peoples have customary Judiciary mechanisms capable of solving community problems based on collective agreements and various existing sanctions show that customary justice in the community is able to provide a sense of justice in handling cases that occur in the community. This shows that the revitalization of customary judiciary needs to be done as a sub-system in the juvenile criminal justice system in Indonesia.

\section{References}

1. E. A. Zulfa, Keadilan Restoratif (Badan Penerbit FH UI, Jakarta, 2009)

2. V. Ness, Daniel W, Jihnstone, Gerry, Hand Book of Restorative Justice, (Willan Publishing, USA, Portland, Oregon, 2007)

3. H. Geertz, The Javanese Family, a Study of Kinds and Socialization, (The Free Press of Giencoe, New York,1961)

4. S. Rahardjo, Hukum Adat Dalam Negara Kesatuan Republik Indonesia, mentioned in the workshop of Customary Law, held by Constitutional Court, Jakarta, on $4-6$ June 2005.

5. S. Rahardjo, Hukum dalam Jagat Ketertiban, (Penerbit UKI Press, Jakarta, 2006)

6. J. Braithwite, Setting Standards for Restorative Justice, The Brit. J. of Crim., Volume 42, 3, 1 (2002)

7. A. Wahyono, Rahayu, Siti, Tinjauan tentang Peradilan Anak di Indonesia, (Sinar Grafika, Jakarta, 1993)

8. Muladi, Proyeksi Hukum Pidana Materiil Indonesia di Masa Datang, Pidato Pengukuhan Guru Besar, (Universitas Diponegoro, Semarang, 1990)

9. Banakar and Travers in S. Irianto, Memperkenalkan Kajian Sosio Legal Dan Implikasi Metodologisnya, Socio Legal Study, (Pustaka Larasan, Denpasar, 2012). 